\title{
Clinicopathologic features of ovarian neoplasms with emphasis on borderline ovarian tumors: an institutional perspective
}

\author{
Atif Ali Hashmi ', Zubaida Fida Hussain ', Aneel Roy Bhagwani ${ }^{1}$, Muhammad Muzzammil Edhi ${ }^{3}$, Naveen Faridi ${ }^{1}$, \\ Syed Danish Hussain ${ }^{2}$ and Mehmood Khan ${ }^{4^{*}}$
}

\begin{abstract}
Background: Ovarian cancer is the most lethal gynecologic malignancy and it represents third most common malignancy in Karachi (after breast and oral cancer). Due to lack of well established cancer registry in our country, changing trends of ovarian tumors has not been determined. Therefore we aimed to establish the current trends and classification of ovarian tumors in our setup according to latest WHO guidelines.

Methods: We retrospectively analyzed 162 cases of ovarian tumors that underwent surgical resection from January 2009 till December 2014. Specimens were received in histopathology department, Liaquat National hospital and cases were examined by senior histopathologists and classified according to latest WHO guidelines. Various histopathologic parameters including capsular invasion, omental and lymph node meatstasis along with uterine and fallopian tube involvement were determined apart from tumor type and grade.

Results: Mean age at diagnosis was 35.8 years ( \pm 15.5 ). surface epithelial tumors were most common, 109 cases (67.2 \%) followed by germ cell tumors, 44 cases (27.1 \%) and sex cord stromal tumors, 8 cases (4.9\%). Serous tumors were most common surface epithelial tumors with $90 \%$ benign morphology. On the other hand, mucinous tumors showed a higher percentage of borderline and malignant features (16.7 and $14.6 \%$ respectively). Higher incidence of capsular invasion and omental metastasis was noted in endometroid and serous carcinoma compared to mucinous tumors.

Conclusions: We noted a higher frequency of young age ovarian cancers in our set up. Serous and endometroid carcinomas were found to be associated with adverse prognostic factors like capsular invasion and omental metastasis. Moreover a significantly higher proportion of ovarian tumors constitute mucinous histology including borderline tumors. Whether this represents a changing trend towards biology of these tumors in this part of the world needs to be uncovered by further studies.
\end{abstract}

Keywords: Ovarian tumors, Pakistan, Mucinous ovarian tumors

\section{Background}

Ovarian cancer is the most lethal gynecologic malignancy and owing to lack of early symptoms and screening protocol, it is detected late in the clinical course of the disease. The worldwide incidence rate is $6.3 / 100,000$ women and is the seventh most common cancer diagnosis.

\footnotetext{
*Correspondence: mehmoodkhan955@yahoo.com

${ }^{4}$ Intern, Dhaka Medical College, Dhaka, Bangladesh

Full list of author information is available at the end of the article
}

Ovarian cancer is the third most malignancy in Karachi (after breast and oral cancer) with an age standardized incidence rate of $10.9 \%$ [1]. The high incidence of ovarian cancer in this part of the world may be due to uncovered BRCA mutations in our population, but this is yet to be fully determined.

One of the unique characteristics of ovarian tumors are their capacity to undergo peritoneal metastasis in the absence of invasive growth in the ovary [13]. This has led to the concept of borderline tumors with a strict 
histologic criteria not influenced by its metastatic counterpart in the peritoneum. Due to lack of well established cancer registry in our country, changing trends of ovarian tumors has not been determined. Therefore we aimed to establish the current trends and classification of ovarian tumors in our setup according to latest WHO guidelines.

\section{Methods}

We retrospectively analyzed 162 cases of ovarian tumors that underwent surgical resection from January 2009 till December 2014. During this period of time, all cases with a provisional diagnosis of ovarian tumors requiring surgical treatment were included in the study. Out of the 162 cases included in the study, 35 had a provisional or frozen section diagnosis of malignancy and thus underwent bilateral oophorectomy along with total abdominal hysterectomy and omental, pelvic lymph nodes sampling. On the other hand, 127 cases were benign and thus underwent oophorectomy only. All specimens were received in histopathology department, Liaquat National hospital. After gross examination, representative sections were stained with hematoxylin and eosin stains. Immunohistochemical stains were applied when necessary. Cases were examined by senior histopathologists and classified according latest WHO guidelines. Various histopathologic parameters including capsular invasion, omental and lymph node metastasis along with uterine and fallopian tube involvement were determined apart from tumor type and grade.

\section{Results}

Mean age at diagnosis was 35.8 years $( \pm 15.5)$. Surface epithelial tumors were most common, 109 cases (67.2\%) followed by germ cell tumors, 44 cases $(27.1 \%)$ and sex cord stromal tumors, 8 cases $(4.9 \%)$. Serous tumors were most common surface epithelial tumors with $90 \%$ benign morphology. On the other hand mucinous tumors showed a higher percentage of borderline and malignant features (16.7 and $14.6 \%$ respectively). Malignant surface epithelial tumors were significantly seen to be more common in older age group compared to their benign and borderline counterparts (Table 1). Malignant surface epithelial tumors also tend to had larger sizes compared to benign and borderline cases (Table 2). Table 3 shows various histopathologic parameters of ovarian tumors. Higher incidence of capsular invasion and omental metastasis was noted in endometroid and serous carcinoma compared to mucinous tumors. On the other hand, high frequency of ovarian capsular involvement was seen in malignant germ cell tumors and fibrosarcoma. Uterine and cervical involvement was also noted in a subset of serous and mucinous carcinomas.
Table 1 Age distribution of ovarian tumors

\begin{tabular}{|c|c|c|c|c|}
\hline & \multicolumn{4}{|c|}{ Age groups } \\
\hline & $\begin{array}{l}<20 \text { years } \\
n(\%)\end{array}$ & $\begin{array}{l}20-40 \text { years } \\
n(\%)\end{array}$ & $\begin{array}{l}40-60 \text { years } \\
n(\%)\end{array}$ & $\begin{array}{l}>60 \text { years } \\
\mathrm{n}(\%)\end{array}$ \\
\hline \multicolumn{5}{|c|}{ Surface epithelial tumor } \\
\hline Benign & $14(17.1)$ & $44(53.7)$ & $18(22)$ & $6(7.3)$ \\
\hline Borderline & $2(25.0)$ & $4(50)$ & $2(25)$ & $0(0)$ \\
\hline Malignant & $0(0)$ & $7(38.9)$ & $4(22.2)$ & $7(38.9)$ \\
\hline \multicolumn{5}{|c|}{ Germ cell tumor } \\
\hline Benign & $3(8.1)$ & $27(73.0)$ & $5(13.5)$ & $2(5.4)$ \\
\hline Malignant & $4(66.7)$ & $2(33.3)$ & $0(0)$ & $0(0)$ \\
\hline \multicolumn{5}{|c|}{ Sex cord stromal tumor } \\
\hline Benign & $1(14.3)$ & $3(42.9)$ & $0(0)$ & $3(42.9)$ \\
\hline Malignant & $0(0)$ & $1(100.0)$ & $0(0)$ & $0(0)$ \\
\hline \multicolumn{5}{|c|}{ Metastatic tumor } \\
\hline Malignant & $0(0)$ & $0(0)$ & $1(100)$ & $0(0)$ \\
\hline
\end{tabular}

Table 2 Tumor size distribution of ovarian neoplasms

\begin{tabular}{|c|c|c|c|c|c|}
\hline & \multirow{2}{*}{$\begin{array}{l}\text { Tumor size } \\
\text { Mean }\end{array}$} & \multicolumn{4}{|c|}{ Tumor size category } \\
\hline & & $\begin{array}{l}<5 \mathrm{~cm} \\
\mathrm{n}(\%)\end{array}$ & $\begin{array}{l}5-10 \mathrm{~cm} \\
\mathrm{n}(\%)\end{array}$ & $\begin{array}{l}10-20 \mathrm{~cm} \\
\mathrm{n}(\%)\end{array}$ & $\begin{array}{l}>20 \mathrm{~cm} \\
\mathrm{n}(\%)\end{array}$ \\
\hline \multicolumn{6}{|c|}{ Surface epithelial tumor } \\
\hline Benign & 10.31 & $15(18.3)$ & $36(43.9)$ & $27(32.9)$ & $4(4.9)$ \\
\hline Borderline & 19.56 & $0(0)$ & $0(0)$ & $6(66.7)$ & $3(33.3)$ \\
\hline Malignant & 19.08 & $1(5.6)$ & $3(16.7)$ & $6(33.3)$ & $8(44.4)$ \\
\hline \multicolumn{6}{|c|}{ Germ cell tumor } \\
\hline Benign & 10.41 & $4(10.5)$ & $19(50)$ & $13(34.2)$ & $2(5.3)$ \\
\hline Malignant & 14.15 & $1(16.7)$ & $0(0)$ & $4(66.7)$ & $1(16.7)$ \\
\hline \multicolumn{6}{|c|}{ Sex cord stromal tumor } \\
\hline Benign & 15.07 & $0(0)$ & $2(28.6)$ & $4(57.1)$ & $1(14.3)$ \\
\hline Malignant & 23.0 & $0(0)$ & $0(0)$ & $0(0)$ & $1(100.0)$ \\
\hline \multicolumn{6}{|c|}{ Secondary malignancy } \\
\hline Malignant & 6.0 & $0(0)$ & $1(100)$ & $0(0)$ & $0(0)$ \\
\hline
\end{tabular}

\section{Discussion}

Ovarian cancers are the most common malignancies of the female genital tract and the 6th leading cancer in USA. It is estimated that the lifetime risk of developing an ovarian cancer among females is 1 in 70 [1]. Ovarian carcinomas are a heterogeneous group of neoplasms showing diverse morphological characteristics, mechanisms of pathogenesis and clinical features [2]. According to morphological features, ovarian tumors are classified as surface epithelial tumors, germ cell tumors, sex cord stromal tumors and metastatic tumors. The mean age of patients with these tumors is 63 years with $80 \%$ of the tumors occurring after 45 years of age [3]. However our 
Table 3 Histopathologic characteristics of borderline and malignant ovarian tumors

\begin{tabular}{|c|c|c|c|c|c|c|c|}
\hline & $\begin{array}{l}\text { Capsular inva- } \\
\text { sion }\end{array}$ & $\begin{array}{l}\text { Omental metas- } \\
\text { tasis }\end{array}$ & $\begin{array}{l}\text { Pelvic lymph } \\
\text { node metas- } \\
\text { tasis }\end{array}$ & $\begin{array}{l}\text { Uterine } \\
\text { involvement }\end{array}$ & $\begin{array}{l}\text { Cervical } \\
\text { involvement }\end{array}$ & $\begin{array}{l}\text { Contalat- } \\
\text { eral ovarian } \\
\text { involvement }\end{array}$ & $\begin{array}{l}\text { Fallopian tube } \\
\text { involvement }\end{array}$ \\
\hline & n (\%) & n (\%) & n (\%) & n (\%) & n (\%) & n (\%) & n (\%) \\
\hline \multicolumn{8}{|l|}{ Borderline } \\
\hline Serous tumours & $0(0)$ & $0(0)$ & $0(0)$ & $0(0)$ & $0(0)$ & $0(0)$ & $0(0)$ \\
\hline $\begin{array}{l}\text { Mucinous } \\
\text { tumours }\end{array}$ & $0(0)$ & $0(0)$ & $0(0)$ & $0(0)$ & $0(0)$ & $0(0)$ & $0(0)$ \\
\hline \multicolumn{8}{|l|}{ Malignant } \\
\hline Serous tumours & $2(50)$ & $1(25)$ & $1(25)$ & $1(25)$ & $0(0)$ & $0(0)$ & $1(25)$ \\
\hline $\begin{array}{l}\text { Mucinous } \\
\text { tumours }\end{array}$ & $1(14.3)$ & $2(28.6)$ & $1(14.3)$ & $1(14.3)$ & $1(14.3)$ & $0(0)$ & $1(14.3)$ \\
\hline $\begin{array}{l}\text { Endometrioid } \\
\text { carcinoma }\end{array}$ & $3(75)$ & $2(40)$ & $0(0)$ & $1(20)$ & $0(0)$ & $0(0)$ & $3(60)$ \\
\hline $\begin{array}{l}\text { Transitional cell } \\
\text { car }\end{array}$ & $0(0)$ & $1(100)$ & $0(0)$ & $0(0)$ & $0(0)$ & $0(0)$ & $0(0)$ \\
\hline Dysgerminoma & $1(50)$ & $1(50)$ & $0(0)$ & $1(50)$ & $1(50)$ & $0(0)$ & $0(0)$ \\
\hline Yolk sac tumor & $1(100)$ & $0(0)$ & $0(0)$ & $0(0)$ & $0(0)$ & $0(0)$ & $0(0)$ \\
\hline Fibrosarcoma & $1(100)$ & $0(0)$ & $0(0)$ & $0(0)$ & $0(0)$ & $0(0)$ & $0(0)$ \\
\hline
\end{tabular}

study shows that the mean age of tumors has significantly lower and more cases of ovarian tumors were seen in females at comparatively younger ages. Approximately $40 \%$ of malignant surface epithelial ovarian tumors were found in an age group of 20-40 years. Due to lack of cancer registries in our country, the demographics of ovarian cancer are poorly understood. Various studies conducted in our population revealed a lower age group distribution of breast cancer in this part of the world due to probable BRCA mutations may play a role in young age ovarian cancer as well [4]. Liaquat National Hospital is one of the largest tertiary care centre of the province and represents both rural and urban patient population of all age groups, therefore lower age distribution of ovarian cancer in our study don't represent hospital demographics.

The distribution of these tumors shows variations in the incidence globally. Surface epithelial tumors were found to be the most common ovarian tumors. The incidence of these tumors in our study (67.2\%) is comparable to a previous study done in the same region [5]. However studies done from other areas of Pakistan have shown slight variation in the incidence of these tumors. The frequency of surface epithelial tumors from Punjab province was found to be $57 \%$ [6] and KPK province was found to be $76.5 \%$ respectively [7]. Surface epithelial tumors were followed by germ cell tumors and sex cord stromal tumors. The frequency of these tumors was found to be 27 and $4.9 \%$ respectively in our study comparable to the literature from other parts of the country $[6,7]$.

In our study majority of these tumors were benign and only a few cases of borderline and malignant category were found. The most common tumors were benign serous tumors accounting for $90 \%$ of the serous surface epithelial tumors and $44.9 \%$ of all surface epithelial tumors, mostly presenting in females of the reproductive age group. However our study is almost consistent with the findings of study done by Ghartimagar et al. which showed an incidence of benign serous surface epithelial tumors $49.4 \%$ among of all surface epithelial tumors [8].

Benign serous tumors were followed by mucinous and endometroid tumors. It was noted that although majority of mucinous tumors were benign there was a higher incidence of mucinous tumors of the borderline category. Literature shows that the majority of the mucinous tumors are benign, $20 \%$ borderline and $5 \%$ invasive [9]. A recent review by J. Prat showed similar results indicating that majority of mucinous tumors i.e., $80 \%$ are benign remainder are borderline and $3-4 \%$ of the tumors being malignant [10]. On the other hand, our study showed similar results for the benign and borderline categories but there was a higher incidence of invasive mucinous neoplasms, $14.6 \%$ compared to $5 \%$ cited in literature. This shows that the incidence of invasive mucinous tumors is much higher in our population as compared to literature from the west.

Germ cell tumors comprised of $27 \%$ of all the ovarian neoplasms in our study. Of which majority of these tumors $(86 \%)$ were mature teratomas whereas rests of the tumors were malignant germ cell neoplasms. This proportion of germ cell tumors corresponded to the results of a study done in India by Mondal et al. however the similar study showed a slightly higher numbers 
of other germ cell tumors which were not present in our study [11].

Sex cord stromal tumors accounted for $4.9 \%$ of all ovarian neoplasms and majority of tumors comprised of benign tumors. The incidence of these tumors corresponds with literature as being the least common subtype of ovarian tumors $[12,13]$. The main limitation of this study is that it is a single center experience and thus referral bias may be a limiting factor.

\section{Conclusions}

We found a higher frequency of young age ovarian cancers in our setup. Serous and endometroid carcinomas were found to be associated with adverse prognostic factors like capsular invasion and omental metastasis. Moreover a significantly higher proportion of ovarian tumors constitute mucinous histology including borderline tumors. Whether this represents a changing trend towards biology of these tumors in this part of the world needs to be uncovered by further studies.

\section{Authors' contributions}

AAA and ZFH were clinical investigators of this study. ARB and MME analyzed the data and wrote the manuscript, and NF, SDH and MK critically revised it. All authors read and approved the final manuscript.

\section{Author details}

${ }^{1}$ Department of Histopathology, Liaquat National Hospital and Medical College, Karachi, Pakistan. ${ }^{2}$ Liaquat National Hospital and Medical College, Karachi, Pakistan. ${ }^{3}$ Intern, Liaquat National Hospital and Medical College, Karachi, Pakistan. ${ }^{4}$ Intern, Dhaka Medical College, Dhaka, Bangladesh.

\section{Acknowledgements}

We acknowledge all members of histopathology department, Liaquat national hospital and medical college, Karachi, Pakistan for their cooperation.

\section{Competing interests}

The authors declare that they have no competing interests.

\section{Ethics approval and consent to participate}

Written informed consent was obtained from the patients for publication of this article and accompanying tables. It mean that all patients, at the time of surgery, agreed that data from their tumor samples will be use in future clinical research. A copy of the written consent is available for review by the Editorin-Chief of this journal. Approval obtained from Liaquat national hospital and medical college ethical review committee.
Received: 3 July 2015 Accepted: 29 March 2016

Published online: 06 April 2016

\section{References}

1. Hennessy BT, Suh GK, Markman M. Ovarian Cancer. In: Kantarjian HM, Wolff RA, Koller CA, editors. The MD Anderson Manual of Medical Oncology. 10 May 2015 from http://accessmedicine.mhmedical.com/content. aspx?bookid $=379 \&$ Sectionid $=39902056$.

2. Mc Cluggage WG. My approach to and thoughts on the typing of ovarian carcinomas. J Clin Pathol. 2008;61:152-63.

3. Ries LAG, Harkins D, Krapcho M, Mariotto A, Miller BA, Feuer ES, Clegg L, Horner MJ, Howlader N, Eisner MP, Richman M, Edwards BK. (eds). SEER Cancer Statistics Review, 1975-2004, National Cancer Institute. Bethesa. http://seer.cancer.gov/csr/1975_2004/, Nov 2006 SEER data submission, posted to the SEER website 2007.

4. Hashmi AA, Edhi MM, Naqvi H, Khurshid A, Faridi N. Molecular subtypes of breast cancer in South Asian population by immunohistochemical profile and Her2neu gene amplification by FISH technique: association with other clinicopathologic parameters. Breast J. 2014;20(6):578-85.

5. Ahmad Z, Kayani N, Hasan SH, Muzaffar S, Gill MS. Histological pattern of ovarian neoplasma. JPMA. 2000;50:416-9.

6. Javed I, Aurangzaib A, Azra N, Afshan S. Pattern of ovarian pathologies. J Rawalpindi Med Coll. 2013;17(1):113-5.

7. Yasmin S, Yasmin A, Asif M. Clinicohistological pattern of ovarian tumours in Peshawar region. J Ayub Med Coll Abbottabad. 2008;20(4):11-3.

8. Ghartimagar D, Ghosh A, Ranabhat S, Talwar OP. Surface epithelial tumors of-an analysis in a tertiary referral hospital. J Pathol Nepal. 2013;3:397-402

9. Clement P, Young R. Ovarian Surface Epithelial-Stromal Tumors. In: Mills S, Carter D, Greenson J, Reuter V, Stoler M, editors. Sternberg's diagnostic surgical pathology. 5th ed. LWW: Philadelphia; 2009. p. 2280.

10. Prat J. New insights into ovarian cancer pathology. Annal Oncol. 2012;23(suppl 10):x111-7.

11. Mondal SK, Banyopadhyay R, Nag DR, Roychowdhury S, Mondal PK, Sinha SK. Histologic pattern, bilaterality and clinical evaluation of 957 ovarian neoplasms: a 10-year study in a tertiary hospital of eastern India. J Can Res Ther. 2011;7:433-7.

12. Hoffman BL, Schorge JO, Schaffer JI, Halvorson LM, Bradshaw KD, Cunningham F, Calver LE. Ovarian Germ Cell and Sex Cord-Stromal Tumors. In: Hoffman BL, Schorge JO, Schaffer Jl, Halvorson LM, Bradshaw KD, Cunningham F, Calver LE, editors. Williams Gynecology. New York: McGrawHill; 2012. http://accessmedicine.mhmedical.com/content.aspx?bookid= 399\&Sectionid=41722327. Accessed 07 Jun 2015.

13. Bell DA, Weinstock MA, Scully RE. Peritoneal implants of ovarian serous borderline tumors. Histologic features and prognosis. Cancer. 1988;62(10):2212-22.

Submit your next manuscript to BioMed Central and we will help you at every step:

- We accept pre-submission inquiries

- Our selector tool helps you to find the most relevant journal

- We provide round the clock customer support

- Convenient online submission

- Thorough peer review

- Inclusion in PubMed and all major indexing services

- Maximum visibility for your research

Submit your manuscript at www.biomedcentral.com/submit

C Biomed Central 